\title{
Pengembangan Kurikulum Berbasis Pendidikan Karakter
}

\author{
Andi Atma \\ Dosen IAI Ibrahimi Sukerejo Sitobondo \\ atma@gmail.com
}

\begin{abstract}
Abstrak
Pengembangan kurikulum berbasis karakter adalah sebagai kegiatan yang berupaya untuk menyusun/ merancang (desain) kurikulum baru, mengubah dan menyempur-nakan/memperbaiki kurikulum, implementasi kurikulum, serta pengendalian kurikulum pendidikan Dasar. Pengendalian ini meliputi monitoring dan evaluasi kurikulum, serta penyempurnaan kurikulum berdasarkan masukan dari hasil monitoring dan evaluasi terhadap kurikulum pendidikan dasar yang telah dipraktikkan di jalur institusi pendidikan sekolah maupun luar sekolah dengan berbagai jenis dan ragamnya

Nilai nilai yang dijadikan pijakan dalam pengembangan kurikulum haruslah bersumber dari nilai agama, pancasila, budaya, dan tujuan pendidikan nasional. Nilai nilai yang bersumber dari empat pilar tersebut diejawanthakan dalam 18 nilai yaitu Religius, Jujur, Toleransi, Disiplin, Kerja Keras, Kreatif, Mandiri, Demokratis, Rasa Ingin Tahu, Semangat Kebangsaan, Cinta Tanah Air, Menghargai Prestasi, Bersahabat/Komunikatif, Cinta Damai, Gemar Membaca, Peduli Lingkungan, Peduli Sosial, dan Tanggung-jawab.
\end{abstract}

Kata Kunci : Pengembangan Kurikulum 


\section{A. LATAR BELAKANG MASALAH}

Kata karakter sesungguhnya berasal dari bahasa Latin: "kharakter", "kharassein", "kharax", dalam bahasa Inggris: character, dalam bahasa Indonesia: "karakter", dan dalam bahasa Yunani: character, dari charassein yang berarti membuat tajam, membuat dalam. ${ }^{1}$ Hendro Darmawan mengartikan karakter sebagai watak, tabiat, pembawaan, dan kebiasaan. ${ }^{2}$ Pengertian yang tidak berbeda juga dikemukakan Dharna Kesuma yang mengatakan bahwa arti kata karakter adalah budi pekerti, akhlak, moral, afeksi, susila, tabiat, dan watak. ${ }^{3}$

Karakter dipengaruhi oleh faktor genetis dan faktor lingkungan seseorang. Pada sisi faktor lingkungan maka karakter seseorang banyak dibentuk oleh orang lain yang sering berada di dekatnya atau yang sering mempengaruhinya, kemudian ia mulai meniru untuk melakukannya.

Misalnya, seorang siswa Madrasah Ibtidaiyah yang masih polos seringkali mengikuti tingkah laku orang tuanya atau teman mainnya, bahkan pengasuhnya. Karena karakter terbentuk dari proses meniru yaitu melalui proses melihat, mendengar dan mengikuti, maka karakter sesungguhnya dapat diajarkan atau diinternalisasi secara sengaja melalui aktivitas pendidikan dengan mengembangkan kurikulum yang berbasis pendidikan karakter". Dengan demikian maka dapat disimpulkan bahwa karakter adalah merupakan hadiah Tuhan yang di bawa sejak lahir dan kemudian berinteraksi dengan lingkungan sekitarnya melalui aktivitas belajar.

Strategi pengembangan kurikulum berbasis pendidikan karakter dapat dilakukan melalui tiga (3) hal, yaitu: 1) mengintegrasikan butir-butir nilai karakter ke dalam seluruh mata pelajaran, muatan lokal dan kegiatan pengembangan diri, 2) pembiasaan dalam kehidupan sehari-hari di sekolah (pelayanan, pengelolaan dan pengajaran), dan 3) meningkatkan kerjasama antara sekolah, orang tua peserta

\footnotetext{
${ }^{1}$ Abdul Majid dan Dian Andayani, Pendidikan Karakter Perspektif Islam, (PT. Remaja Rosdakarya, 2011), hlm. 11

2 Hendro Darmawan, dkk., Kamus Ilmiah Populer Lengkap, (Yogyakarta: Bintang Cemerlang, 2010), hlm. 277

3 Dharma Kesuma, dkk., Pendidikan Karakter; Kajian Teori dan Praktik di Sekolah, (Bandung: PT. Remaja Rosdakarya, 2011), hlm. 24.
} 
didik, dan masyarakat dalam hal membudayakan/membiasakan nilai-nilai karakter di lingkungan sekolah, lingkungan rumah tangga dan lingkungan masyarakat.

Dasar pelaksanaan pendidikan karakter sesungguhnya adalah berlandasakan kepada tujuan pendidikan nasional dan pesan dari UU Sisdiknas tahun 2003 yang mengharapkan agar pendidikan tidak hanya membentuk manusia yang pintar namun juga berkepribadian (berkarakter), sehingga nantinya akan lahir generasi muda yang tumbuh dan berkembang dengan kepribadian yang bernafaskan nilainilai luhur Agama dan Pancasila. Demikian pula halnya di dalam Standar Kelulusan (SKL) Madrasah Ibtidaiyah ditemukan bahwa sebagian besar hasil belajar adalah merupakan pembentukan nilai-nilai karakter yang baik di dalam diri peserta didik, seperti: karakter beriman dan bertaqwa kepada Tuhan, bertanggungjawab, jujur, dan disiplin.

Namun, strategi penerapan pendidikan karakter tersebut ternyata belum terlaksana dengan baik di beberapa sekolah dan Madrasah. Sebab, fokus sebagian lembaga pendidikan dewasa ini masih pada pembekalan ilmu pengetahuan dan skill untuk bekerja sehingga siswa mampu bersaing dan mempertahankan hidupnya. Sedangkan pembentukan watak, karakter atau ahlak nyaris hampir tidak diperhatikan dan inilah pendidikan yang selama ini terlupakan, padahal karakter inilah yang menentukan pada arah masa depan yang lebih cerah. Suatu bangsa akan mengalami keterpurukan disebabkan karena tidak memiliki karakter yang baik. hal itulah yang mengakibatkan bangsa ini terpuruk dan tidak keluar dari krisis multi dimensi.

Atas dasar inilah, pendidikan kita harus dikelola dengan baik dan benar agar dapat menghasilkan lulusan yang lebih berkualitas dan siap menghadapi "dunia" masa depan yang penuh dengan problema dan tantangan serta dapat menghasilkan lulusan yang memiliki karakter mulia, yakni: memiliki kepandaian sekaligus kecerdasan, memiliki kreativitas tinggi sekaligus sopan dan santun dalam berkomunikasi, serta memiliki kejujuran dan kedisiplinan sekaligus memiliki tanggung jawab yang tinggi. Dengan kata lain, pendidikan harus mampu mengemban misi pembentukan karakter (character building) sehingga para peserta didik dan para lulusannya dapat berpartisipasi dalam mengisi 
pembangunan dengan baik dan berhasil tanpa meninggalkan nilai-nilai karakter mulia.

\section{B. PEMBAHASAN}

\section{Pengertian Pengembangan Kurikulum Berbasis Karakter}

Pengembangan berasal dari kata dasar kembang yang berarti menjadi bertambah sempurna. Kemudian mendapat imbuan pe-dan - an sehingga menjadi pengembangan yang artinya proses, cara atau perbuatan mengembangkan. ${ }^{4}$ Jadi pengembangan di sini adalah usaha sadar yang dilakukan untuk mencapai tujuan yang diinginkan agar lebih sempurna dari pada sebelumnya.

Menurut Iskandar dan Usman Mulyadi, kurikulum adalah program pendidikan yang disediakan oleh sekolah untuk siswa, melalui program yang direncanakan tersebut siswa melakukan berbagai kegiatan belajar sehingga mendorong perkembangan dan pertumbuhannya sesuai dengan pendidikan yang telah ditentukan. ${ }^{5}$

Wynne mengatakan bahwa ada dua pengertian karakter. Pertama, istilah karakter menunjukkan bagaimana bertingkah laku,apabila seseorang berperilaku tidak jujur, kejam, atau rakus, maka orang tersebut memanifestasikan karakter jelek, sebaliknya apabila seseoran berprilaku jujur, suka menolong, maka orang tersebut mamanifestasikan karakter yang mulia.Kedua, istilah karakter erat kaitannya dengan "personality". Seseorang bisa disebut "orang berkarakter" kalau tingkah lakunya sesuai dengan kaidah moral. ${ }^{6}$

Karakter ini mirip dengan ahlak yang berasal dari kata Khuluk, yaitu tabiat atau kebiasaan melakukan hal-hal yang baik. Imam al-Gazali menggambarkan bahwa karakter (akhlak) adalah tingkah laku seseorang yang berasal dari hati yang baik.

Jadi pengembangan kurikulum berbasis pendidikan karkater adalah sebagai kegiatan yang berupaya untuk menyusun/ merancang (desain) kurikulum baru,

\footnotetext{
${ }^{4}$ Depdikbud, Kamus Besar Bahasa Indonesia, (Jakarta: Balai Pustaka, 1989) hlm.414

${ }^{5}$ Iskandar W dan Drs. Usman Mulyadi, Dasar-dasar Pengembangan Kurikulum, (Jakarta: Bina Aksara, 1988) hlm. 6

${ }^{6}$ Ratna Megawati, Character Parenting Space (Bansdung: Read 2007), 9.
} 
mengubah dan menyempur-nakan/memperbaiki kurikulum, implementasi kurikulum, serta pengendalian kurikulum pendidikan Dasar.

Pengendalian ini meliputi monitoring dan evaluasi kurikulum, serta penyempurnaan kurikulum berdasarkan masukan dari hasil monitoring dan evaluasi terhadap kurikulum pendidikan dasar yang telah dipraktikkan di jalur institusi pendidikan sekolah maupun luar sekolah dengan berbagai jenis dan ragamnya.

\section{Nilai-nilai Pendidikan Budaya dan Karakter Bangsa}

Nilai-nilai yang dikembangkan dalam pendidikan budaya dan karakter bangsa diidentifikasi dari sumber-sumber berikut ini.

a) Agama: masyarakat Indonesia adalah masyarakat beragama. Oleh karena itu, kehidupan individu, masyarakat, dan bangsa selalu didasari pada ajaran agama dan kepercayaannya. Secara politis, kehidupan kenegaraan pun didasari pada nilai-nilai yang berasal dari agama. Atas dasar pertimbangan itu, maka nilai-nilai pendidikan budaya dan karakter bangsa harus didasarkan pada nilai-nilai dan kaidah yang berasal dari agama.

b) Pancasila: negara kesatuan Republik Indonesia ditegakkan atas prinsipprinsip kehidupan kebangsaan dan kenegaraan yang disebut Pancasila. Pancasila terdapat pada Pembukaan UUD 1945 dan dijabarkan lebih lanjut dalam pasalpasal yang terdapat dalam UUD 1945. Artinya, nilai-nilai yang terkandung dalam Pancasila menjadi nilai-nilai yang mengatur kehidupan politik, hukum, ekonomi, kemasyarakatan, budaya, dan seni. Pendidikan budaya dan karakter bangsa bertujuan mempersiapkan peserta didik menjadi warga negara yang lebih baik, yaitu warga negara yang memiliki kemampuan, kemauan, dan menerapkan nilai-nilai Pancasila dalam kehidupannya sebagai warga negara.

c) Budaya: sebagai suatu kebenaran bahwa tidak ada manusia yang hidup bermasyarakat yang tidak didasari oleh nilai-nilai budaya yang diakui masyarakat itu. Nilai-nilai budaya itu dijadikan dasar dalam pemberian makna terhadap suatu konsep dan arti dalam komunikasi antaranggota masyarakat itu. Posisi budaya yang demikian penting dalam kehidupan 
masyarakat mengharuskan budaya menjadi sumber nilai dalam pendidikan budaya dan karakter bangsa.

d) Tujuan Pendidikan Nasional: sebagai rumusan kualitas yang harus dimiliki setiap warga negara Indonesia, dikembangkan oleh berbagai satuan pendidikan di berbagai jenjang dan jalur. Tujuan pendidikan nasional memuat berbagai nilai kemanusiaan yang harus dimiliki warga Negara Indonesia. Oleh karena itu, tujuan pendidikan nasional adalah sumber yang paling operasional dalam pengembangan pendidikan budaya dan karakter bangsa.

Berdasarkan keempat sumber nilai itu, teridentifikasi sejumlah nilai untuk pendidikan budaya dan karakter bangsa sebagai berikut ini.

\section{Tabel 1}

\section{Deskripsi Nilai Pendidikan Budaya dan Kaarakter Bangsa}

\begin{tabular}{|c|c|l|}
\hline No & Nilai & \multicolumn{1}{c|}{ Deskripsi } \\
\hline 1 & Religius & $\begin{array}{l}\text { Sikap dan perilaku yang patuh dalam melaksanakan ajaran } \\
\text { agama yang dianutnya, toleran terhadap pelaksanaan ibadah } \\
\text { agama lain dan hidup rukun dengan pemeluk agama lain }\end{array}$ \\
\hline 2 & Jujur & $\begin{array}{l}\text { Perilaku yang didasarkan pada upaya } \\
\text { menjadikan dirinya sebagai orang yang selalu } \\
\text { dapat dipercaya dalam perkataan, tindakan, dan } \\
\text { pekerjaan. }\end{array}$ \\
\hline 3 & Toleransi & $\begin{array}{l}\text { Sikap dan tindakan yang menghargai perbedaan } \\
\text { agama, suku, etnis, pendapat, sikap, dan tindakan } \\
\text { orang lain yang berbeda dari dirinya. }\end{array}$ \\
\hline 4 & Disiplin & $\begin{array}{l}\text { Tindakan yang menunjukkan perilaku tertib dan } \\
\text { patuh pada berbagai ketentuan dan peraturan }\end{array}$ \\
\hline 6 & Kerja & $\begin{array}{l}\text { Perilaku yang menunjukkan upaya sungguhsungguh } \\
\text { dalam mengatasi berbagai hambatan } \\
\text { belajar dan tugas, serta menyelesaikan tugas } \\
\text { dengan sebaik-baiknya. }\end{array}$ \\
\hline 7 & Keras & $\begin{array}{l}\text { Berpikir dan melakukan sesuatu untuk } \\
\text { menghasilkan cara atau hasil baru dari sesuatu } \\
\text { yang telah dimiliki. }\end{array}$ \\
\hline 8 & $\begin{array}{r}\text { Demokrati } \\
\text { s }\end{array}$ & $\begin{array}{l}\text { Sikap dan perilaku yang tidak mudah tergantung } \\
\text { pada orang lain dalam menyelesaikan tugas. }\end{array}$ \\
\hline $\begin{array}{l}\text { Cara berfikir, bersikap, dan bertindak yang } \\
\text { menilai sama hak dan kewajiban dirinya dan } \\
\text { orang lain }\end{array}$ \\
\hline
\end{tabular}




\begin{tabular}{|c|c|c|}
\hline No & Nilai & Deskripsi \\
\hline 9 & $\begin{array}{l}\text { Rasa Ingin } \\
\text { Tahu }\end{array}$ & $\begin{array}{l}\text { Sikap dan tindakan yang selalu berupaya untuk } \\
\text { mengetahui lebih mendalam dan meluas dari } \\
\text { sesuatu yang dipelajarinya, dilihat, dan didengar. }\end{array}$ \\
\hline 10 & $\begin{array}{l}\text { Semangat } \\
\text { Kebangsaa } \\
n\end{array}$ & $\begin{array}{l}\text { Cara berpikir, bertindak, dan berwawasan yang } \\
\text { menempatkan kepentingan bangsa dan negara di } \\
\text { atas kepentingan diri dan kelompoknya }\end{array}$ \\
\hline 11 & $\begin{array}{c}\text { Cinta } \\
\text { Tanah Air }\end{array}$ & $\begin{array}{l}\text { Cara berfikir, bersikap, dan berbuat yang } \\
\text { menunjukkan kesetiaan, kepedulian, dan } \\
\text { penghargaan yang tinggi terhadap bahasa, } \\
\text { lingkungan fisik, sosial, budaya, ekonomi, dan } \\
\text { politik bangsa. }\end{array}$ \\
\hline 12 & $\begin{array}{l}\text { Mengharga } \\
\text { i Prestasi }\end{array}$ & $\begin{array}{l}\text { Sikap dan tindakan yang mendorong dirinya } \\
\text { untuk menghasilkan sesuatu yang berguna bagi } \\
\text { masyarakat, dan mengakui, serta menghormati } \\
\text { keberhasilan orang lain }\end{array}$ \\
\hline 13 & $\begin{array}{l}\text { Bersahabat } \\
\text { /Komunikti } \\
\quad \mathrm{f}\end{array}$ & $\begin{array}{l}\text { Tindakan yang memperlihatkan rasa senang } \\
\text { berbicara, bergaul, dan bekerja sama dengan } \\
\text { orang lain. }\end{array}$ \\
\hline 14 & $\begin{array}{l}\text { Cinta } \\
\text { Damai }\end{array}$ & $\begin{array}{l}\text { Sikap, perkataan, dan tindakan yang } \\
\text { menyebabkan orang lain merasa senang dan } \\
\text { aman atas kehadiran dirinya. }\end{array}$ \\
\hline 15 & $\begin{array}{c}\text { Gemar } \\
\text { Membaca }\end{array}$ & $\begin{array}{l}\text { Kebiasaan menyediakan waktu untuk membaca } \\
\text { berbagai bacaan yang memberikan kebajikan } \\
\text { bagi dirinya. }\end{array}$ \\
\hline 16 & $\begin{array}{l}\text { Peduli } \\
\text { Lingkunga } \\
n\end{array}$ & $\begin{array}{l}\text { Sikap dan tindakan yang selalu berupaya } \\
\text { mencegah kerusakan pada lingkungan alam di sekitarnya, } \\
\text { dan mengembangkan upaya-upaya } \\
\text { untuk memperbaiki kerusakan alam yang sudah terjadi. }\end{array}$ \\
\hline 17 & $\begin{array}{l}\text { Peduli } \\
\text { Sosial }\end{array}$ & $\begin{array}{l}\text { Sikap dan tindakan yang selalu ingin memberi } \\
\text { bantuan pada orang lain dan masyarakat yang } \\
\text { membutuhkan. }\end{array}$ \\
\hline 18 & $\begin{array}{l}\text { Tanggung- } \\
\text { jawab }\end{array}$ & $\begin{array}{l}\text { Sikap dan perilaku seseorang untuk } \\
\text { melaksanakan tugas dan kewajibannya, yang } \\
\text { seharusnya dia lakukan, terhadap diri sendiri, } \\
\text { masyarakat, lingkungan (alam, sosial dan } \\
\text { budaya), negara dan Tuhan Yang Maha Esa }\end{array}$ \\
\hline
\end{tabular}

\section{Strategi Pengembangan Kurikulum Berbasis Pendidikan Karakter}

Sebagaimana yang telah kita ketahui, bahwa manusia diciptakan dengan dibekali berbagai potensi yang harus ditumbuh kembangkan, sehingga potesi tersebut sesuai dengan fungsi diciptakannya manusia itu sediri yaitu sebagai wakil Allah SWT dalam rangka untuk memelihara alam ini. 
Jadi pembentukan karakter adalah merupakan suatu keharusan dan bahkan menjadi tujuan diselenggarakannya pendidikan. Hal itu pula yang menjadi tujuan diutusnya Nabi Muhammad Saw ketengah-tengah masyarakat jahiliyah, sebagaimana sabdanya dalam sebuah Hadist bahwa, sesungguhnya nabi saw di utus untuk menyempurnakan akhlak.

Pendidikan karakter (akhlak) dalam Islam menekankan penanaman sikap dan perilaku yang baik pada diri individu, sehingga ia mampu berbuat baik bagi dirinya dan masyarakatnya. Hubungan individu dengan masyarakat dalam islam, merupakan hubungan timbal balik, yang diikat oleh nilai dan norma etika yang disebut oleh Aminah Ahmad Hasan dengan istilah 'il_qah rūhiyyah khuluqiyah' (interaksi yang diikat oleh kode etik). ${ }^{7}$

Oleh karena itu, untuk membentuk karakter anak dapat dilakukan dengan berbagai macam pendekatan, selain yang dijelaskan diatas, pembentukan karakter anak dapat dilakukan dengan sikap sebagai berikut $:^{8}$

\section{a) Keteladanan}

Keteladanan adalah merupakan sebuah sikap dan perilaku yang muncul dari hati nurani yang paling dalam, sehingga apa yang dilakukukan tidak menyimpang dari kehendak Tuhan dan norma-norma yang ada ditengah-tengah masyarakat. Oleh karena itu dalam mendidik manusia Allah menggunakan contoh atau teladan sebagai model terbaik agar mudah diserap dan diterapkan oleh manusia.

Oleh karena itu, dalam membentuk karakter anak, keteladanan merupakan pendekatan pendidikan yang paling ampuh. Misalnya dalam keluarga, orang tua yang diamanahi berupa anak-anak harus menjadi teladan yang baik, dalam lingkup sekolah maka guru yang menjadi teladan bagi anak didik dalam segala hal. Tanpa keteladanan apa yang diajarkan kepada anak didik hanya akan menjadi teori belaka. Jadi, keteladanan guru dalam berbagai aktivitasnya akan menjadi cermin siswanya, Oleh sebab itu sosok guru yang bisa diteladani siswa adalah guru yang mempunyai jiwa dan karakter yang islami.

\footnotetext{
${ }^{7}$ Aminah ahmad Hasan, nazariyah al-Tarbiyah fi al-Qur'ān wa-Tatbiqātuha fi Ahdi Rasulillah SAW (Qairo: Dār al-Mā ārif, 1985), 32.

${ }^{8}$ Furqon Hidayatullah, Penbdidikan Karakter Membangun Peradaban Bangsa, (Surakarta: Yuma Pustaka, 2010), 39.
} 


\section{b) Penanaman Kedisiplinan}

Amiroeddin Sjarif mengatakan bahwa kedisiplinan pada dasarnyaadalah suatu ketaatan yang sungguh-sungguh yang didukung oleh kesadaranuntuk menunaikan tugas dan kewajiban serta berperilaku sebagaimanamestinya menurut aturan-aturan atau tata kelakuan yang seharusnya berlakudalam suatu lingkungan tertentut.

Dengan demikian, kedisiplinan dalam melaksanakan aturan dalam lingkungan atau kegiatan yang dilakukan secara rutin itu terdapat nilai-nilai yang menjadi tolek ukur tentang benar tidaknya suatu yang dilakukan oleh seseorang. Bentuk kedisiplinan yang diberlakukan adalah merupakan sebuah usaha untuk membentuk karakter individu. ${ }^{9}$

\section{c) Pembiasaan}

Anak akan tumbuh dan berkembang sebagaimana lingkungan yang mengajarinya dan lingkungan tersebut juga yang menjadi kebiasaan yang dihadapinya setiap hari. Jika lingkungan mengajarinya dengan kebiasaan berbuat baik, maka kelak anak akan terbiasa berbuat baik dan sebaliknya jika seorang anak tumbuh dalam lingkungan yang mengajarinya berbuat kejahatan, kekerasan, maka ia akan tumbuh menjadi pelaku kekerasan.

\section{d) Menciptakan Suasana Yang Kondusif}

Terciptanya suasanya yang kondusif akan memberikan iklim yang memungkinkan terbentuknya karakter. Oleh karena itu, berbagai hal yang terkait dengan upaya pembentukan karakter harus dikondisikan, terutama individuindividu yang ada dilakungan itu. ${ }^{10}$

\section{Prosedur Pengembangan Kurikulum Madrasah Ibtidaiyah/ Sekolah Dasar Berbasis Karakter}

Prosedur pengembangan kurikulum berbasis pendidikan karakter adalah beranjak dari problem karakter yang dihadapi sehingga dirasa perlu mengintegrasikan nilai-nilai karakter ke dalam seluruh komponen pendidikan.

\footnotetext{
${ }^{9}$ Ramayulis, Ilmu Pendidikan Islam (Jakarta: Kalam Mulia 2002), 172.

${ }^{10}$ Furqon Hidayatullah, Pendidikan Karakter Membangun Peradaban Bangsa (Surakarta: Yuma Pustaka, 2010), hlm 53.
} 
Prosedur pengembangan kurikulum Madrasah Ibtidaiyah berbasis pendidikan karakter dapat ditempuh melalui langkah-langkah berikut : ${ }^{11}$

\section{a) Sosialisasi}

Tim dari pusat pengembangan kurikulum seharusnya memberikan sosialisasi tentang pendidikan karakter kepada kepala sekolah, guru, dan tenaga kependidikan lainnya. Tujuan sosialisasi adalah untuk menyamakan persepsi tentang konsep pendidikan karakter. Materi sosialisasi antara lain tentang kebijakan kementerian pendidikan nasional, konsep pendidikan karakter dan budaya serta bagaimana mengimplementasikan pendidikan karakter ke dalam Kurikulum Tingkat Satuan Pendidikan (KTSP). Kegiatan sosialisasi tersebut kemudian dilanjutkan pada lingkungan satuan pendidikan dengan melibatkan komite sekolah dan orang tua peserta didik. Tujuannya adalah untuk menyamakan persepsi di antara pendidik dan tenaga kependidikan yang ada di lingkungan satuan pendidikan.

\section{b) Pengembangan Dokumen Kurikulum}

Pengembangan dokumen kurikulum madrasah diawali dengan melakukan identifikasi dan analisis nilai-nilai karakter yang terkandung di dalam Standar Kelulusan madrasah (SKL). Hal ini dilakukan untuk mengetahui nilai-nilai karakter yang perlu diintegrasikan madrasah ke dalam kurikulum tingkat satuan pendidikan (KTSP), baik pada dokumen I dan dokumen II. Hasil analisis terhadap nilai-nilai karakter yang terkandung di dalam SKL kemudian diklasifikasi kepada beberapa aspek karakter, seperti: nilai relegius, nilai toleransi, nilai menghargai waktu, nilai budaya ilmiah dan lain-lain. Adapun rumusan SKL Madrasah Ibtidaiyah dan nilai-nilai karakter yang terkandung di dalamnya adalah sebagai berikut:

\footnotetext{
${ }^{11}$ Kementerian Pendidikan Nasional; Badan Penelitian dan Pengembangan Pusat Kurikulum dan Perbukuan, 2011, Pedoman Pelaksanaan Pendidikan Karakter, (tidak diterbitkan), hlm. 18-25
} 
Tabel 2

\section{Rumusan SKL Pendidikan Karakter}

\begin{tabular}{|c|l|l|}
\hline No. & \multicolumn{1}{|c|}{ Rumusan SKL $^{12}$} & \multicolumn{1}{|c|}{ Nilai Karakter } \\
\hline 1. & $\begin{array}{l}\text { Menjalankan ajaran agama yang dianut sesuai } \\
\text { dengan tahap perkembangan anak }\end{array}$ & $\begin{array}{l}\text { Jujur dan bertanggung } \\
\text { jawab. }\end{array}$ \\
\hline 2. & Mengenal kekurangan dan kelebihan diri sendiri & Jujur \\
\hline 3. & $\begin{array}{l}\text { Mematuhi aturan-aturan sosial yang berlaku dalam } \\
\text { lingkungannya }\end{array}$ & Bertanggung jawab \\
\hline No. & \multicolumn{1}{|c|}{ Rumusan SKL } & Nilai Karakter \\
\hline 4. & $\begin{array}{l}\text { Menghargai keberagaman agama, budaya, suku, ras, } \\
\text { dan golongan sosial ekonomi di lingkungan } \\
\text { sekitarnya }\end{array}$ & Peduli \\
\hline 5. & $\begin{array}{l}\text { Menggunakan informasi tentang lingkungan sekitar } \\
\text { secara logis, kritis, dan kreatif dengan bimbingan } \\
\text { guru/ pendidik }\end{array}$ & Cerdas dan kreatif \\
\hline 6. & $\begin{array}{l}\text { Menunjukkan kemampuan berpikir logis, kritis, dan } \\
\text { kreatif, dengan bimbingan guru }\end{array}$ & Cerdas dan Kreatif \\
\hline 7. & $\begin{array}{l}\text { Menunjukkan rasa keingintahuan yang tinggi dan } \\
\text { menyadari potensinya }\end{array}$ & Bersungguh-sungguh \\
\hline 8. & $\begin{array}{l}\text { Menunjukkan kemampuan memecahkan masalah } \\
\text { sederhana dalam kehidupan sehari-hari }\end{array}$ & Peduli \\
\hline 9. & $\begin{array}{l}\text { Menunjukkan kemampuan mengenali gejala alam } \\
\text { dan sosial di lingkungan sekitar }\end{array}$ & Peduli \\
\hline 10. & $\begin{array}{l}\text { Menunjukkan kecintaan dan kepedulian terhadap } \\
\text { lingkungan }\end{array}$ & Peduli \\
\hline 11. & $\begin{array}{l}\text { Menunjukkan kecintaan dan kebanggaan terhadap } \\
\text { bangsa, negara, dan tanah air Indonesia }\end{array}$ & Cinta tanah Air \\
\hline 12. & $\begin{array}{l}\text { Menunjukkan kemampuan untuk melakukan } \\
\text { kegiatan seni dan budaya lokal }\end{array}$ & Berbudaya \\
\hline 13. & $\begin{array}{l}\text { Menunjukkan kebiasaan hidup bersih, sehat, bugar, } \\
\text { aman, dan memanfaatkan waktu luang }\end{array}$ & Disiplin \\
\hline 14. & Berkomunikasi secara jelas dan santun & Ramah dan santun \\
\hline 15. & $\begin{array}{l}\text { Bekerjasama dalam kelompok, tolong- menolong, } \\
\text { dan menjaga diri sendiri dalam lingkungan keluarga } \\
\text { dan teman sebaya }\end{array}$ & Tolong menolong \\
\hline 16. & Menunjukkan kegemaran membaca dan menulis \\
\hline 17. & $\begin{array}{l}\text { menunjukkan keterampilan menyimak, berbicara, } \\
\text { membaca, menulis, dan berhitung. }\end{array}$ & Teliti \\
\hline
\end{tabular}

${ }^{12}$ Muhaimin, dkk., Pengembangan Model Kurikulum Tingkat Satuan Pendidikan (KTSP), Pada Sekolah dan Madrasah, (Jakarta: Rajawali Pers, 2009), hlm. 189-190 
Hasil pemetaan nilai-nilai karakter tersebut kemudian dijadikan panduan dalam menyusun silabus dan Rencana Pelaksanaan Pengajara (RPP). Setiap point dari Standar Kompetensi (SK) dan Kompetensi Dasar (KD) yang dirumuskan juga dianalisis dan diklasifikasi beberapa nilai-nilai karakter yang terkandung di dalamnya.

Agar mengefektifkan pelaksanaan pendidikan karakter, sekolah perlu membuat suatu jaringan topik yang terintegrasi dengan nilai-nilai karakter pada setiap mata pelajaran, materi muatan lokal dan pengembangan diri.

Untuk mendukung pelaksanaan pendidikan karakter maka manajemen pengelolaan madrasah harus dikondisikan sebagai pendukung kegiatan pendidikan karakter. Pengelolaan sarana madarasah harus mencerminkan kehidupan nilainilai karakter yang diinginkan. Misalnya: toilet yang selalu bersih, bak sampah ada di berbagai tempat dan selalu dibersihkan, madrasah terlihat rapi, alat belajar ditempatkan teratur, disediakan tempat wudhu dan jumlah krannya yang layak, Mushalla atau sejenis ruang shalat yang layak digunakan para siswa dan guru untuk shalat dzuhur berjamaah dan shalat dhuha berjamaah, dan disediakan juga sarana bacaan religious seperti: AlQuran/ Juz Amma dan terjemahannya.

Wujud nilai keterbukaan dalam pengelolaan dan pelayanan sekolah juga menjadi proritas penting dalam pelaksanaan pendidikan karakter. Misalnya Kepala Madarasah harus selalu berkomunikasi dengan semua guru tentang program kerja sekolah, laporan keuangan Madrasah, dan lain sebagainya. Begitu pula guru harus menanamkan nilai-nilai keterbukaan kepada semua anak didiknya, baik dalam pembelajaran di kelas maupun pada kegiatan ekstra kulikuler.

\section{DAFTAR PUSTAKA}

Al-Gazali, Abū Hamid, Ihya Ulumuddin Mesir: Daar al-Taqwa, t.th.

Arikunto, Suharsimi, Prosedur Penelitian Suatu Pendekatan Praktek,Jakarta: Renika Cipta, 1998.

Aunillah, Nurla Isna, Panduan Menerapkan Pendidikan karakter di Sekolah, Yogyakarta: Laksana, 2011. 
Bimo, Walgito, Bimbingan dan Penyuluhan di Sekolah Yogyakaarta: Andi Offset, 1983.

Darmawan, Hendro, dkk., Kamus Ilmiah Populer Lengkap, Yogyakarta: Bintang Cemerlang, 2010.

Hidayatullah, Furqon, Pendidikan Karakter Membangun Peradaban Bangsa Surakarta: Yuma Pustaka 2010.

Kementerian Pendidikan Nasional, Badan Penelitian dan Pengembangan Pusat

Kurikulum, 2010, Pengembangan Pendidikan Budaya dan Karakter Bangsa; Pedoman Sekolah, tidak terbit

Majid, Abdul dan Dian Andayani, Pendidikan Karakter Perspektif Islam, PT. Remaja Rosdakarya, 2011.

Megawati, Ratna, Character Parenting Space, Bandung: Read 2007.

Muhaimin, dkk., Pengembangan Model Kurikulum Tingkat Satuan Pendidikan (KTSP), Pada Sekolah dan Madrasah, Jakarta: Rajawali Pers, 2009. 